\title{
Impact of Integrated Nutrient Management on Growth, Yield and Economics of Garden Pea in Kandhamal District of Odisha, India
}

\author{
S. K. Mukhi ${ }^{1}$, S. Pradhan ${ }^{2}$, D. V. Singh ${ }^{3 *}$ and D. Mishra ${ }^{3}$ \\ ${ }^{1}$ Department of Soil Science, Krishi Vigyan Kendra, Kandhamal, OUAT, Bhubaneswar, India \\ ${ }^{2}$ Department of Agronomy, Krishi Vigyan Kendra, Kandhamal, OUAT, Bhubaneswar, India \\ ${ }^{3}$ Krishi Vigyan Kendra, Kandhamal, OUAT, Bhubaneswar, India \\ *Corresponding author
}

A B S T R A C T

Keywords

Boron, Garden pea,

Lime, INM,

Sulphur, Yield

attributes, Yield \&

Net return

Article Info

Accepted:

24 August 2019

Available Online:

10 September 2019
An experiment was carried out in the Krishi Vigyan Kendra, Kandhamal for finding out the effect of integrated nutrient management in the form of soil amelioration through liming, application of nutrients through inorganic and organic sources on the growth and yield of garden pea (Pisum sativum var. hortense L.). The results revealed that, combined application of $20 \mathrm{~kg}$ sulphur and $01 \mathrm{~kg}$ boron along with incorporation of lime @ $0.2 \mathrm{LR}$, soil test based NPK and FYM @ $05 \mathrm{t} \mathrm{ha}^{-1}$ resulted maximum height of the plant $(96.8 \mathrm{~cm})$, number of branches per plant (4.56), number of nodules per plant (42.4), numbers of pods per plant (24.7), single pod length $(8.44 \mathrm{~cm})$, number of grains per pod (7.43), weight of green pods per plant (34.8 gm), shelling percentage (51.5) and green pod yield (102.8 q ha $\left.{ }^{-1}\right)$. This treatment also came out with highest net return (Rs. 1,14,680/- $\mathrm{ha}^{-1}$ ) and a benefit cost ratio of $1: 3.30$.

\section{Introduction}

Garden pea (Pisum sativum var. hortense L.) is one of the popular winter vegetable crops commercially grown during Rabi season in India and provides variety of protein rich vegetarian dishes for humans. It is usually grown for its green pod containing immature seeds which are cooked alone or mixed with other vegetables and is also processed for freezing, canning and dehydration to meet the consumer's requirement during off-season. This crop occupies 459 thousand hectare area in India and shares 21 percent production of the world (Dhall, 2017). The district Kandhamal in the state of Odisha is favourable for vegetable cultivation due to its agro climatic condition. The district is predominantly inhabited by tribal people who are resource poor \& marginal farmers. They are cultivating different crops in traditional methods and most of them are cultivating 
garden pea in small patches as it is one of most remunerative crops in the district. However, soil acidity and poor nutrient management are the major constraints for getting optimum yield of this crop in the district. Nutrient application trend in this district is very poor $\left(8.3 \mathrm{~kg} \mathrm{ha}^{-1}\right)$ and farmers are generally use lower rate of farmyard manure with rare or no use of secondary and micronutrients.

The major growth-limiting factors associated with acid soil infertility include toxicity of Aluminium (Al) and Manganese (Mn), deficiencies or low availability of certain essential elements including Calcium (Ca), Magnesium (Mg), Phosphorus (P), Boron (B), and Molybdenum (Mo) and very low microbial activity (Thakuria et al 2016). Legume vegetable crops such as pea are sensitive to soil acidity and liming is only option for increasing yield in such soil conditions.

Moreover, from an extensive survey, it was found that, the soils of Kandhamal district are more deficient in S $(82.5 \%)$ and B $(79.2 \%)$ (Nayak and Jena, 2014). Due to these factors, the average productivity of this crop in the district is 68 quintals green pods $\mathrm{ha}^{-1}$.

The productivity of this crop can be increased by adopting the integrated nutrient management practices through application of lime, organic manure, soil test based fertilizer application. However, the information on the requirements for an appropriate combination of nutrients through various sources viz., inorganic fertilizers and organics, including secondary and micronutrient in garden pea is meager in acidic soils of Kandhamal condition. Hence, the present investigation was conducted to assess the effect integrated nutrient management practices on yield attributes, productivity and profitability of garden pea in Kandhamal District of Odisha.

\section{Materials and Methods}

The present study was carried out in the KVK instructional farm during the Rabi seasons of 2016-17 and 2017-18 under irrigated medium land condition. Before sowing the crop, composite soil samples representing the whole field and after harvest plot wise samples were collected for determining the nutrient status. The organic carbon, $\mathrm{pH}$, available $\mathrm{N}, \mathrm{P}$ and $\mathrm{K}$ were analyzed as per the methods described by Jackson (1973). The experimental soil was sandy clay loam in texture, acidic in reaction ( $\mathrm{pH} 5.2)$ and was low in organic carbon content (4.2 $\mathrm{g} \mathrm{kg}^{-1}$ soil), low in available Nitrogen $\left(232.8 \mathrm{~kg} \mathrm{ha}^{-1}\right)$, medium in available Phosphorus $\left(21.3 \mathrm{~kg} \mathrm{ha}^{-1}\right)$, high in available Potassium (301.6 kg ha ${ }^{-1}$ ), low in available Sulphur (8.6 kg ha $\left.{ }^{-1}\right)$ and low in Boron $(0.42$ ppm). The experiment comprised 04 treatments viz. $\mathrm{T}_{1}$ : Farmers' practice (No management practices for soil acidity, application of 20:40:0 kg N: $\mathrm{P}_{2} \mathrm{O}_{5}: \mathrm{K}_{2} \mathrm{O}$ ha $^{-1}$ and FYM @ $01 \mathrm{t} \mathrm{ha}^{-1}$ ), $\mathrm{T}_{2}$ : Application of soil test based fertilizer dose, FYM @ $05 \mathrm{t} \mathrm{ha}^{-1}$ and lime@0.2 LR, T $\mathrm{T}_{3}$ : $\mathrm{T}_{2}+$ application of $20 \mathrm{~kg}$ Sulphur ha ${ }^{-1}$ and $\mathrm{T}_{4}: \mathrm{T}_{3}+$ application of $01 \mathrm{~kg}$ Boron $\mathrm{ha}^{-1}$. The treatments were replicated five times and the experiment was laid out in randomized block design (RBD). Recommended dose of FYM was incorporated manually into the soil one week prior to sowing and lime as paper mill sludge (PMS) was applied @0.2 LR and mixed into the soil as per the treatments. Similarly, sulphur @ 20 $\mathrm{kg} \mathrm{ha}^{-1}$ in the form of elemental sulphur and boron@ $01 \mathrm{~kg} \mathrm{ha}^{-1}$ in the form of borax were applied as basal dose in the respective treatments. Hybrid garden pea cultivar 'GS10 ' was used as the test crop and was sown at a seed rate of $20 \mathrm{~kg} \mathrm{ha}^{-1}$ with a row spacing of $30 \mathrm{~cm}$ and plant to plant spacing of $10 \mathrm{~cm}$. The pods of garden pea were harvested in three pickings at weekly intervals. All the recommended cultural practices were adopted to raise the crop. A sample of ten plants were 
randomly tagged in each treatment and replication for recording data on different growth parameters like plant height $(\mathrm{cm})$, branches/plant, nodules/plant and yield related attributes like pods/plant, pod length $(\mathrm{cm})$, grains/pod, weight of green pods/plant (gm), shelling percentage and green pod yield ( $\mathrm{q}$ ha ${ }^{-}$ $\left.{ }^{1}\right)$. The shelling percentage was calculated by using the formula as follows.

Shelling percentage

$=\frac{\text { Weight of green seeds from } 100 \text { pods }(\mathrm{gm})}{\text { Weight of } 100 \text { pods }(\mathrm{gm})} \times 100$

Economics of garden pea cultivation were calculated by considering the prevalent local market price. The benefit: cost ratio for each treatment was calculated by dividing the total monetary benefits by cost of production. The data thus collected was subjected to analysis of variance, using the method proposed by Panse and Sukhatme (2010).

\section{Results and Discussion}

The growth parameters, pod yield and other yield attributes and economics of this experiment on garden pea showed similar results in two consecutive years. Hence, the pooled data are taken in account for discussion.

\section{Growth parameters}

The effect of integrated nutrient management on the growth parameters of garden pea is depicted in Table-1. The results showed that, maximum amount of growth parameters like plant height $(96.8 \mathrm{~cm})$, no. of branches/plant (4.56) and no. of nodules/plant (42.4) were achieved in $\mathrm{T}_{4}$ followed by $\mathrm{T}_{3}, \mathrm{~T}_{2}$ and $\mathrm{T}_{1}$ and also all the parameters in $\mathrm{T}_{4}$ were significantly higher than the other treatments. Prasad and Prasad (2003) and Singh et al.,(2005) reported that, the amount of $\mathrm{N}, \mathrm{P} \& \mathrm{~K}$ added through chemical fertilizers coupled with the supply of $\mathrm{S}$ was found effective for better plant health and higher yield of garden pea. The increase in growth and growth related attributes of garden pea crop is due to application of sulphur and boron which are responsible for enhancing the metabolism regulation and enzymatic processes including photosynthesis, respiration and symbiotic nitrogen fixation. Improvement in nodule formation and growth of the plants could be due to sulphur and boron for increasing leghaemoglobin pigment formation in nodules. This result is in uniformity with the findings of other workers (Quddus et al., 2018, Parry et al 2016, Azevedo et al., 2002, Hamdaoni et al 2003 and Khana and Gupta 2005).

\section{Yield and yield attributes}

The findings of the investigation revealed that, maximum increase in the yield parameters like number of grains /pod (7.43), pods/plant (24.7), pod weight /plant (34.8 g), single pod length $(8.44 \mathrm{~cm})$ and shelling percentage $(51.5 \%)$ were attained in $\mathrm{T}_{4}$ followed by $\mathrm{T}_{3}$ and $\mathrm{T}_{2}$. However, the lowest mean values of the yield attributing parameters like number of grains /pod (5.13), number of pods / plant (15.2), weight of pods/plant (23.7 g), single pod length $(5.42 \mathrm{~cm})$ and shelling percentage $\left(43.4 \%\right.$ ) were recorded in $\mathrm{T}_{1}$ (farmers' practice).

The pod yield of garden pea in $\mathrm{T}_{4}(102.8 \mathrm{q}$ ha $\left.{ }^{1}\right)$ significantly increased by $8.4,17.9$ and 41.4 per cent over $T_{3}, T_{2}$ and $T_{1}$, respectively. This might be due to application of lime along with balanced fertilization, which helped in translocation of photosynthates resulting in better pod formation as well as grains. These results supported the findings of Shivran et al (2000). Also the initial microbial population helped in mobilizing the unavailable pool of nutrients in soil, thereby triggering the acquisition of optimum nutrient supply across critical crop stages (Singh et al., 2016 and Pandey et al., 2006, Jaipaul et al., 2011, Sephehya 2015). 
Table.1 Effect of INM treatments on the growth parameters of garden pea

\begin{tabular}{|l|l|l|l|}
\hline Treatments & Plant height $(\mathbf{c m})$ & $\begin{array}{l}\text { Number of branches/ } \\
\text { plant }\end{array}$ & $\begin{array}{l}\text { Number of nodule / } \\
\text { plant }\end{array}$ \\
\hline $\mathbf{T}_{\mathbf{1}}$ : Farmers practice & 61.4 & 3.41 & 25.2 \\
\hline $\mathbf{T}_{\mathbf{2}}$ & 74.6 & 3.98 & 32.5 \\
\hline $\mathbf{T}_{\mathbf{3}}$ & 82.5 & 4.29 & 37.6 \\
\hline $\mathbf{T}_{\mathbf{4}}$ & 96.8 & 4.56 & 42.4 \\
\hline S.Em( $\mathbf{( )}$ & 0.58 & 0.17 & 0.51 \\
\hline C.D.(0.05) & 1.78 & 0.51 & 1.57 \\
\hline
\end{tabular}

Table.2 Effect of INM treatments on yield attributes and green pod yield of garden pea

\begin{tabular}{|c|c|c|c|c|c|c|}
\hline Treatments & $\begin{array}{l}\text { Single pod } \\
\text { length }(\mathrm{cm})\end{array}$ & $\begin{array}{l}\text { No. of } \\
\text { grains/po } \\
\text { d }\end{array}$ & $\begin{array}{ll}\text { No. of } \\
\text { pods } \\
\text { /plant }\end{array}$ & $\begin{array}{l}\text { Weight of } \\
\text { green } \\
\text { pod/plant }\end{array}$ & $\begin{array}{l}\text { Shelling } \\
\%\end{array}$ & $\begin{array}{l}\text { Green } \\
\text { pod } \\
\text { yield }(q \\
\left.\text { ha }^{-1}\right)\end{array}$ \\
\hline$T_{1}:$ Farmers' practice & 5.42 & 5.13 & 15.2 & 23.7 & 43.4 & 72.7 \\
\hline $\mathbf{T}_{2}$ & 6.56 & 5.85 & 19.3 & 29.2 & 46.7 & 87.2 \\
\hline $\mathbf{T}_{3}$ & 7.19 & 6.37 & 21.4 & 31.8 & 48.4 & 94.8 \\
\hline $\mathbf{T}_{4}$ & 8.44 & 7.43 & 24.7 & 34.8 & 51.5 & 102.8 \\
\hline $\operatorname{S.Em}( \pm)$ & 0.12 & 0.09 & 0.31 & 0.39 & 0.54 & 0.51 \\
\hline C.D.(0.05) & 0.38 & 0.26 & 0.96 & 1.21 & 1.67 & 1.58 \\
\hline
\end{tabular}

Table.3 Effect of INM treatments on economics of garden pea

\begin{tabular}{|l|l|l|l|l|l|}
\hline Treatments & $\begin{array}{l}\text { Cost of cultivation } \\
\text { (Rs/ha) }\end{array}$ & $\begin{array}{l}\text { Pooled pod } \\
\text { yield(q/ha) }\end{array}$ & $\begin{array}{l}\text { Gross return } \\
\text { (Rs/ha) }\end{array}$ & $\begin{array}{l}\text { Net return } \\
\text { (Rs ha }^{-1} \text { ) }\end{array}$ & $\begin{array}{l}\text { B:C } \\
\text { ratio }\end{array}$ \\
\hline $\mathbf{T}_{\mathbf{1}}$ : Farmers' practice & 42800 & 72.7 & 116320 & 73520 & 2.7 \\
\hline $\mathbf{T}_{\mathbf{2}}$ & 47400 & 87.2 & 139520 & 92120 & 2.9 \\
\hline $\mathbf{T}_{\mathbf{3}}$ & 48000 & 94.8 & 151680 & 103680 & 3.1 \\
\hline $\mathbf{T}_{\mathbf{4}}$ & 49800 & 102.8 & 164480 & 114680 & 3.3 \\
\hline
\end{tabular}

Net return $=$ gross return - cost of cultivation

Improvement in pod yield and related attributes in garden pea due to sulphur and boron application could be attributed to fulfilment of crop demand by higher assimilation and translocation of photosynthesis from leaves to seeds and with increasing sulphur and boron, the process of tissue differentiation from somatic to reproductive, meristematic activity and development of floral primordia might have increased resulting in more flowers and higher seed yield. Similar observations have also been reported by other workers in garden pea and other crops (Nasreen and Farid, 2003, Parry et al 2016 and Kumar et al 2012).

\section{Economics}

The economics of the experimentation was calculated based on the existing market price of the green pods. The economics in terms of gross and net return for each treatment were 
worked out. Among the treatments, maximum net return of Rs. 1,14,680/- $\mathrm{ha}^{-1}$ and cost benefit ratio (1:3.3) was recorded in $\mathrm{T}_{4}$ (Table 3). This might be due to reclamation of soil acidity along with balanced fertilization including boron and sulphur increased the pod yield. This treatment combination $\left(\mathrm{T}_{4}\right)$ was found to be the most economical than other treatments. Whereas, the lowest net return of Rs. 73,520/- $\mathrm{ha}^{-1}$ and cost benefit ratio (1:2.7) were recorded with the farmer's practice $\left(\mathrm{T}_{1}\right)$. Parry et al (2016) reported that maximum net return of Rs.1,41,243/- ha $^{-1}$ was observed due to combined application of $30 \mathrm{~kg}$ sulphur and $2 \mathrm{~kg}$ boron $\mathrm{ha}^{-1}$ along with RDF in garden pea. Dubey et al (2012) also reported that, combined application of organic and inorganic fertilizers increased the net benefit and cost benefit ratio in garden pea cultivation.

Based on this study, it is concluded that, combined application of $20 \mathrm{~kg}$ sulphur and 01 $\mathrm{kg}$ boron along with incorporation of lime @ 0.2 LR, soil test based NPK and FYM @ 05 t $\mathrm{ha}^{-1}$ is an optimum nutrient combination for enhancing growth, pod yield, other yield attributes and profitability of garden pea in acid soils of Kandhamal district of Odisha.

\section{References}

Azevedo,W.D., Faqium,V., Moreeira,F.S., Oliveira,A. and Lisboacc,D.S. (2002). Boron effect on nodule development in pea plants cultivated in lowland soils, Pesquisa Agrope Curia Brasileria, 37:1137-1143

Dhall, R.K. (2017). Pea cultivation : Bulletin No. PAU/2017/Elec/FB/E/29.

Dubey, D.K., Singh,S.S., Verma,R.S. and Singh,P.K. (2012). Integrated nutrient management in garden pea (Pisum sativum var. hortense), Horticultural Flora Research Spectrum, 1:244-247

Hamdaoni,A., Redondo,N.M., Rivilla,R. and Bolonos,L. (2003). Effect of boron and calcium nutrition on the establishment of the rhizobium leguminosarum pea (Pisum sativum) symbiosis and nodule development under salt stress. Plant Cell and Environment, 26:1003-1011

Jackson, M. L. (1973). Soil Chemical Analysis, Prentice Hall of India Private Limited, New Delhi.

Jaipaul,S., Dixit, A. and Sharma, A.K. (2011). Growth and yield of capsicum (Capsicum annum) and garden pea (Pisum sativum) as influenced by organic manures and biofertilizers, Indian Journal of Agricultural Science, 81(7):637-642.

Khana,P.K. and Gupta,A.K. (2005). Changes in growth, yield and some biochemical attributes in pea (Pisum sativum) with rhizobium and sulphur application, Journal of Plant Biology, 32:25-28

Kumara,A., Singh,O.N. and Kumar,R. (2012). Effect of integrated nutrient management on growth, seed yield and economics of pea (Pisum sativum) and fertility changes, J.Food Leg, 25:121124.

Nasreen,S. and Farid,A.T.M (2003). Influence of different nutrients on growth and yield of garden pea (Pisum sativum), Indian Journal of Agronomy, 48:206209

Nayak, R.K. and Jena, B (2014). Annual Progress Report 2013-14, AICRP on micro and secondary nutrients and pollutant elements in soils and plants. pp : 10

Pandey,A.K., Gopinath,K.A., Bhattacharya,R., Hooda, K.S., Sushil,S.N., Kundu,S., Selvakumar, G. and Gupta,H.S. (2006). Effect of source and rate of organic manures on yield attributes, pod yield and economics of garden pea grown under organic farming system, Indian Journal of Agricultural Science, 76(4):230-234

Panse, V.G and Suhatme, P.V. (2010). 
Statstical methods for agricultural works, ICAR, New Delhi

Parry, F.A. Chattoo, M.A., Magray, M., Ganie, S.A., Dar, Z.M. and Masood, A. (2016). Effect of Different Levels of Sulphur and Boron on growth and nodulation of garden Pea (Pisum sativum L.), Legume Research, 39(3) : 466-469.

Prasad,K. and Prasad,R. (2003). Effect of varities and sulphur on yield and yield attributes of field pea (Pisum sativum var. arvense), Crop Research, 25(3):419-422

Quddus, M.A., Hossain, M.A., Naser, H.M., Anwar, B, Aktar, S and Nazimuddin, M. (2018). Effect of zinc and boron application on productivity, quality and nutrient uptake of field pea (Pisum Sativum L.) grown in calcarious soils, Journal of Agricultural Science and Practice (JASP), 3(6)132-143

Sephehya,S., Bharadwaj,S.K., and Dhiman, S. (2015) Quality attributes of garden pea (Pisum sativum L.) as influenced by integrated nutrient management under mid hill conditions. Journal of Krishi Vigyan, 3(2):78-83

Shivran, P.L., Ahlawat, I.P.S. and Shivran, D.R. (2000). Effect of phosphorus and sulphur on pigeon pea (Cajanus cajan) and succeeding wheat (Triticum aestivum) in pigeon pea-wheat cropping system. Indian Journal of Agronomy, 45(1): 25-30.

Singh,M., Deokaran and Bhatt, B.P. (2016).Effect of Integrated Nutrient Management on Soil Fertility Status, Productivity and Profitability of Garden Pea, Journal of Krishi Vigyan $5(1): 29-33$.

Singh,R.K., Singh,J., De,N. and Rai,M. (2005). Integrated nutrient management influences yield and nodulation of pea, Vegetable Science, 32(1):59-61.

Thakuria, D., Hazarika, S and Krishnappa, R. (2016). Soil Acidity and Management Options, Indian Journal of Fertilisers, 12 (12), 40-56.

\section{How to cite this article:}

Mukhi, S. K., S. Pradhan, D. V. Singh and Mishra, D. 2019. Impact of Integrated Nutrient Management on Growth, Yield and Economics of Garden Pea in Kandhamal District of Odisha, India. Int.J.Curr.Microbiol.App.Sci. 8(09): 2465- 2470.

doi: https://doi.org/10.20546/ijcmas.2019.809.285 